\title{
Origin of the Redwater River Drainage Basin Determined by Topographic Map Interpretation: Eastern Montana, USA
}

\author{
Eric Clausen $^{1}$ \\ ${ }^{1}$ Independent Researcher, Jenkintown PA \\ Correspondence: Eric Clausen, 100 West Ave D-17, Jenkintown, PA 19046. E-mail: eric2clausen@gmail.com
}

Received: November 15, 2018

Accepted: January 2, 2019

Online Published: February 26, 2019

doi:10.5539/jgg.v11n1p42

URL: http://dx.doi.org/10.5539/jgg.v11n1p42

\begin{abstract}
Topographic and geologic map interpretation strongly suggests the eastern Montana Redwater River valley eroded headward across large southeast-oriented ice-marginal melt water floods. The north-oriented Redwater River heads in an area to the south of recognized continental glaciation and flows into the recognized glaciated region before joining the east-oriented Missouri River. Detailed topographic maps show the eastern drainage divide is asymmetric with steeper slopes on the Redwater River side and is crossed by shallow dry valleys linking northwestoriented Redwater River tributaries with southeast-oriented streams that flow as barbed tributaries to the northeastoriented Yellowstone River. The western drainage divide is also crossed by shallow dry valleys linking northwestoriented drainage routes to north-oriented Missouri River tributaries with southeast-oriented and barbed tributaries to the northeast- and north-oriented Redwater River. Alluvium from upstream Yellowstone River source areas found within the Redwater River drainage basin suggests the Redwater River and much longer Yellowstone River valleys eroded headward from a continental ice sheet margin as headward erosion of the larger Yellowstone River valley across the southeast-oriented flood flow was supplemented by northeast- and north-oriented flow moving at the present day Redwater-Yellowstone River drainage divide elevation.
\end{abstract}

Keywords: aligned drainage, barbed tributary, Bell River system, drainage divide origin, Missouri River, Yellowstone River

\section{Introduction}

The Redwater River originates on the east central Montana plains (see Figure 1) and drains a larger north-oriented valley than the present-day river and drainage basin size justify before joining the east-oriented Missouri River opposite the south-oriented Popular River valley. The Missouri River after entering North Dakota turns in a south direction with water eventually reaching the Mississippi River and the Gulf of Mexico. The Redwater River drainage area is approximately 5100 square kilometers in size and is located in McCone, Dawson, Richland, and Prairie Counties, Montana, where elevations now range from 1094 meters at Big Sheep Mountain near the Redwater River headwaters to slightly below 600 meters where the Redwater River joins the Missouri River. The northeast-oriented Yellowstone River valley is to the east and south of the Redwater River drainage basin and a high asymmetric drainage divide separates the two north-oriented Missouri River tributaries. Sand Creek, the longer Prairie Creek, and the even longer Big Dry Creek drainage basins are located to the west and southwest of the Redwater River drainage basin and like the Redwater River drain in north directions to the Missouri River. The Sand, Prairie, and Big Dry Creek valleys do not give the impression of being oversized as the much larger Redwater River valley does. This paper addresses the question of how the large north-oriented Redwater River valley originated.

The relatively short, but large Redwater River valley (177 kilometers in length) originates to the south of mapped glacially deposited materials and extends in a north direction to enter a region where glacially deposited sediments are draped across much of the region (Alden, 1932 and Howard, 1960). Alden's map is based on fieldwork done several years previous to the 1932 publication date and shows glacial sediments covering the Redwater River drainage basin's northern half and a hypothesized ice-marginal river channel cutting across the central Redwater River drainage basin along the mapped glacial sediment southern margin. No glacial sediments are shown to the south of that channel. Both Alden and Howard considered the Redwater River valley to have been eroded prior to the deposition of the glacial sediments and assumed glacial ice had blocked the north-oriented Redwater River valley, which they interpreted to have joined a pre-glacial northeast-oriented Missouri River which had flowed 
through the abandoned valley shown by the $\mathrm{V}$ in figure 1 to eventually reach the present-day Hudson Bay area. Howard (1960) mapped what he described as early Wisconsin (?) drift to be covering the Redwater River drainage basin's northern half. While the Redwater River drainage basin southern half lacked evidence of glacially deposited sediments Howard states a thin lobe of glacial ice dammed the north-oriented Redwater River to form what he refers to as Glacial Lake Circle, although he states "there are no recognizable shorelines."

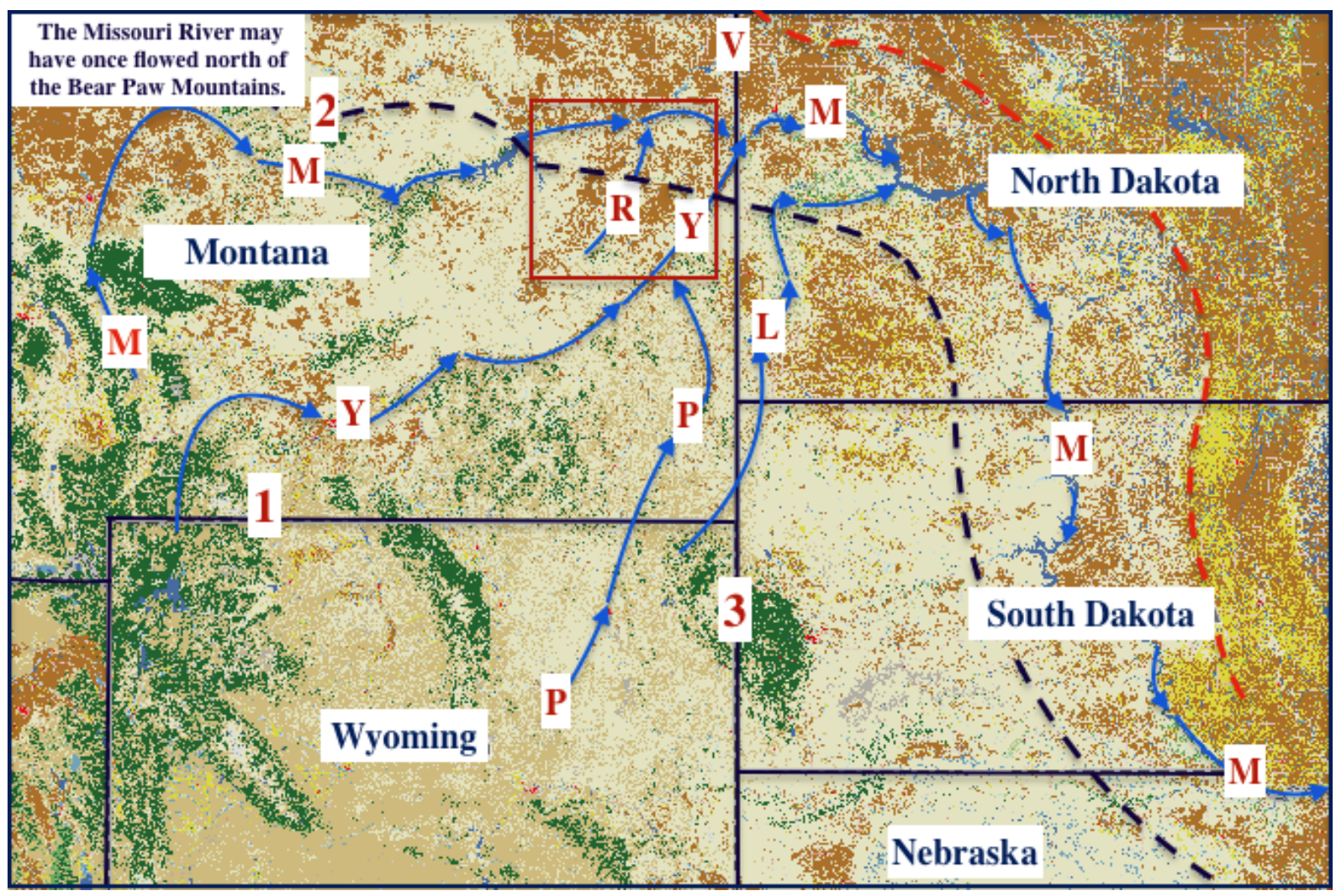

Figure 1. Modified map from United States Geological Survey (USGS) National Map website showing the Redwater River (R) location in this paper's study region (red rectangle) and its relationship to the Missouri River

(M), Yellowstone River (Y), Powder River (P), Little Missouri River (L), Missouri Escarpment (dashed red line), and an abandoned valley now partially filled by glacially deposited materials (V). The Beartooth Mountains are at location 1, Bear Paw Mountains at location 2, and Black Hills at location 3. The dashed black line shows approximate southern and western limit of mapped glacial erratics

Davis (2004) describes Glacial Lake Circle as one of "at least six large pro-glacial lakes on the southern edge of the Laurentide ice sheet (Colton et al., 1961)", however others see the lake's existence, at least as described, as questionable. Perhaps the best evidence for the lake's existence are scattered glacial erratic boulders found in the Redwater River valley to the south of mapped glacial sediments and of a well-defined valley across the RedwaterYellowstone River drainage divide that Howard and others suggest was the Glacial Lake Circle outlet channel. Parker (1936) suggested the erratic boulders found to the south of the glacial sediment margin had been rafted on icebergs that had floated on the surface of a lake formed where the then ice-marginal Missouri River had been ponded in the pre-glacial Redwater River valley. Parker states, "The ice sheet probably caused little change in the topography of the area over which it passed. The deposits of till are thin and small and form only small hummocks. The writer concludes that the ice sheet was perhaps only a few hundred feet [meters] thick and not heavily loaded with detritus."

Wilde and Smith (2003) in their map of the Richey quadrangle, which includes much of central Redwater River drainage basin, show discontinuous areas of glacial till in northern quadrangle areas, but no Quaternary sediments except for small and widely scattered patches of gravel in regions where Glacial Lake Circle should have existed. The Wilde and Smith map and similar maps of adjacent regions also show bedrock underlying the Redwater River drainage basin to be similar to bedrock underlying nearby and modern-day North Dakota and eastern Montana Missouri River valley reservoirs, where well-defined shorelines quickly developed in regions underlain by the 
same bedrock types. How a glacially dammed lake of the type described could have filled the Redwater River valley without developing similar shorelines and without leaving some evidence of lacustrine sedimentary deposits is difficult to explain. Yet if the large and north-oriented Redwater River valley existed at the time when an ice sheet margin blocked it such a lake should have formed. If the lake did not exist as described then what alternate hypothesis explains the scattered erratic boulders and the well-defined outlet valley?

Perhaps more serious than the lack of identifiable Lake Circle shorelines and the scarcity of lacustrine sediments is the implication that continental ice sheets and continental ice sheet melt water did not deeply erode the easily eroded underlying regional bedrock. Yet early workers including Todd (1914), Leonard (1916), Flint (1955), and Howard (1958) have the described the north-oriented Missouri River headwaters, Yellowstone and Powder Rivers, Little Missouri River, and other north- and northeast-oriented Missouri River tributaries (including the Redwater River) as components of a major pre-glacial north-oriented drainage system, now named in the geologic literature as the Bell River system, which is illustrated in papers by McMillan (1971), Sears (2013), and others. Evidence for the Bell River system includes abandoned valleys, now partially filled with glacially deposited materials, that extend in northeast and north directions across glaciated regions to the north and east of the present-day Montana and North Dakota Missouri River valley. Those abandoned valleys document a north-oriented drainage system that did exist prior to development of what are considered to be ice-marginal Missouri River valley segments. However, many segments of those abandoned valleys are eroded in the easily eroded regional bedrock and White (1972 and 1988) questioned how such valleys could survive continental ice sheet erosion effects.

White's alternative to having continental ice sheets daintily tiptoe across the easily eroded northern plains region bedrock, as the pre-glacial age of the Bell River valley system hypothesis implies, was to propose a deep erosion by continental ice sheets hypothesis. While addressing some evidence White's deep erosion by continental ice sheets hypothesis could not explain other evidence including how the abandoned north-oriented valleys now containing glacially deposited materials had originated and as a result the hypothesis was strongly criticized (e.g. Sugden, 1976). White's critics were correct that White's hypothesis did not provide a good explanation for the abandoned north-oriented Bell River drainage system, yet White had a valid point when he criticized the preglacial age of the north-oriented Bell River drainage system. Abandoned Bell River drainage system valleys now partially filled with glacially deposited materials definitely exist to the north and northeast of the present-day North Dakota and Montana Missouri River valley and the north-oriented Redwater River valley leads directly to one of those abandoned valleys. However simple common-sense logic suggests the continental ice sheet(s) and the melt water from those ice sheets should have deeply eroded the easily eroded regional bedrock and should have completely destroyed any pre-glacial valleys crossing the region.

Recent papers by Clausen (e.g. 2017a, 2017b, 2018a, 2018b, 2018c, 2018d), which were written after extensive study of Missouri River drainage basin detailed topographic map evidence, describe how the north-oriented Bell River drainage system developed during a North American continental ice sheet's final melting stages. The ice sheet in question had created (by deep erosion and ice sheet caused crustal warping) a deep "hole". As that large ice sheet melted large south-oriented supra-glacial rivers sliced deep ice-walled and bedrock-floored canyons into the ice sheet's surface. Because the ice sheet was located in a deep "hole" the ice-walled canyon floors were lower in elevation than areas over which immense ice-marginal melt water floods were flowing. In time the ice-marginal floods spilled across the decaying ice sheet's southwestern margin and entered a southeast- and south-oriented icewalled canyon (the Missouri Escarpment in Figure 1 is what remains of that canyon's southwest and west wall). Those spillages enabled northeast- and north-oriented valleys to erode headward in sequence from the southeast to the northwest from the ice-walled canyon into the ice-marginal regions and across the massive ice-marginal floods. At first melt water flowing on the floor of the ice-walled canyon moved in a south direction, but as the ice sheet decayed much shorter northeast- and north-oriented routes to sea level developed and the north-oriented Bell River drainage system gradually evolved. However, as massive melt water floods were diverted from the Gulf of Mexico to the North Atlantic the climate changed and freezing melt water floods filled the ice-walled canyon floors (between decaying ice sheet remnants) and created a new and much thinner ice sheet. The new ice sheet did not deeply erode, but it blocked the newly formed northeast- and north-oriented drainage routes and forced water to flow along the new ice sheet's margin and to create the present-day northeast Montana and North and South Dakota Missouri River valley route.

Clausen's hypothesis defines a new and fundamentally different glacial history paradigm that not only explains how the north-oriented Bell River drainage system developed, but also explains how a second and much thinner ice sheet deposited material in Bell River drainage system valleys located to the north and northeast of the North and South Dakota and eastern Montana Missouri River valley. However, to be accepted by the any scientific research community a new and fundamentally different paradigm according to Kuhn (1965) must demonstrate its 
ability to answer questions the previously accepted paradigm cannot answer and to open up research opportunities the previous paradigm cannot provide. The detailed topographic map investigation reported here was undertaken for the purpose of demonstrating that Clausen's new and fundamentally different glacial history paradigm does successfully explain origins of previously unexplained and/or poorly explained Redwater River drainage basin landforms.

\section{Research Method}

This study represents one small component of a much larger project, which began in 1980 by determining the origin of distinctive igneous cobbles found in southwest North Dakota Oligocene and younger alluvium. The material had been transported from somewhere else and most published literature argued for a Black Hill source, although Denson and Gill (1965) claimed the alluvium did not match Black Hills rock types and had been derived from the Montana Beartooth Mountains (location 1 on Figure 1), however a later worker claimed no match with Beartooth Mountains sources. Since the published literature appeared to rule out all suggested source areas this author decided to test a hypothesis that continental ice sheet ice-marginal melt water floods had transported the alluvium in a southeast direction from the north central Montana Bear Paw Mountains (location 2 on Figure 1). After trying to match rock types and checking alluvium throughout eastern Montana that hypothesis as initially proposed had to be rejected, but the study determined the alluvium had Yellowstone River drainage basin source areas including the Beartooth Mountains as Denson and Gill had proposed. Also, that study found the distinctive alluvium abundant along the high Redwater-Yellowstone River drainage divide and also present in much of the Redwater River drainage basin.

The distinctive alluvium distribution did suggest a large northeast-oriented river flowing from the Beartooth Mountain area into eastern Montana and on a topographic surface equivalent in elevation to the present day Redwater-Yellowstone River drainage divide had been (partially?) diverted at the location of a recognized continental ice sheet margin to flow in an east and southeast direction into southwest North Dakota. However, the logical conclusion defied commonly accepted geologic histories. Some of the distinctive alluvium is contained in mapped southwest North Dakota Oligocene sediments usually interpreted to significantly predate North American continental glaciation. Further, between the Redwater-Yellowstone River drainage divide location (where the northeast-oriented river carrying the distinctive alluvium must have flowed when blocked by a continental ice sheet) and the southwest North Dakota distinctive alluvium deposits are the deep northeast-oriented Yellowstone River valley and the deep north-oriented Little Missouri River valley, both of which have been interpreted to be components of the pre-glacial north-oriented Bell River system (McMillan, 1973 and Sears, 2013).

After many unsuccessful attempts to explain the distinctive alluvium distribution in ways consistent with the commonly accepted regional geologic histories a decision was made to use detailed topographic maps and topographic map interpretation methods to determine where at the time of the continental ice sheet's maximum advance (dashed black line position in Figure 1) continental ice sheet melt water had flowed. Major drainage divides (between what previous investigators have suggested are pre-glacial north- and northeast-oriented streams and rivers) immediately to the south and west of the mapped maximum continental ice sheet advance were studied and dry valleys now crossing those drainage divides were interpreted to have been eroded as melt water and iceblocked drainage was forced to flow along the ice sheet margin. Numerous such dry valleys exist including deeper valleys previous investigators had suggested served as outlets for various ice-dammed lakes, such as Glacial Lake Circle. However, none of the deeper dry valleys was judged to be large enough to handle the projected ice-marginal flow (the projected volume of ice-marginal flow was judged to have been significantly greater, at least on hot summer days, than modern day Missouri River flow during major flood events).

Since in the Redwater River drainage basin area (and also in similar ice-marginal drainage basin areas investigated while doing the larger project) the deepest dry valleys crossing each drainage divide to the south and west of the continental ice sheet margin were judged to be too small to handle the probable amount of ice marginal flow detailed topographic maps were used to determine other locations where ice-marginal flow could have crossed each of the drainage divides. That investigation meant checking all drainage divides surrounding the Redwater River drainage basin and also surrounding all similar ice-marginal area drainage basin drainage divides. Numerous closely spaced shallower dry valleys were found to be crossing the drainage divides surrounding the Redwater River drainage basin as reported here (and crossing almost all Missouri River drainage basin drainage divides the larger project investigated) and like the deeper dry valleys the closely spaced shallower dry valleys crossing Redwater River drainage basin drainage divides linked headwaters of northwest-oriented tributaries to a northoriented stream or river on the drainage divide's western side with headwaters of southeast-oriented barbed tributaries to a north-oriented streams or rivers on the drainage divide's eastern side. Multiple streams of southeastoriented ice-marginal flow were interpreted to have eroded these shallower dry valleys. Erosion of the closely 
spaced shallower dry valleys was interpreted to have been by anastomosing complexes of diverging and converging flood flow channels that prior to headward erosion of the much deeper north-oriented valleys (on either side of the drainage divide) had crossed the entire region.

Southeast-oriented and barbed tributaries to the north- and northeast-oriented Redwater River were interpreted to have originated as southeast-oriented ice-marginal flood flow channels. Headward erosion of the much deeper north- and northeast-oriented Redwater River valley was interpreted to have captured and beheaded the southeastoriented flood flow channels and to have caused reversals of flow on the northwest ends of the beheaded channels, which initiated the northwest-oriented tributaries. Because the flood flow channels diverged and converged and because the much deeper north-oriented valleys eroded headward across the large southeast-oriented ice-marginal floods, the reversed flow in newly beheaded and reversed flow channels captured southeast-oriented flood flow still moving to the south of the actively eroding and much deeper north- or northeast-oriented Redwater River valley head. Such captures were necessary to erode the northwest-oriented slope and tributary valleys. The larger project initially used thousands of hard-copy detailed topographic maps and was later repeated using National Geographic TOPO software and topographic maps. Research notes for the second larger study are found at gemorphologyresearch.com. This paper presents results for the much smaller eastern Montana Redwater River drainage basin, which was restudied using detailed topographic maps found at the USGS National Map website.

\section{Results}

\subsection{Redwater River Headwaters Area}

The modified topographic map shown in Figure 2 illustrates the Redwater River headwaters area and shows northwest-oriented tributaries to north-oriented Big Dry Creek in the region south and west of the Redwater River headwaters (Big Dry Creek flows to the Missouri River). Also shown are headwaters of southeast-oriented tributaries to the northeast-oriented Yellowstone River. These Yellowstone River tributaries are located south of the Redwater River headwaters and east of the northwest-oriented Big Dry Creek drainage basin. The Redwater River drainage basin's highest point is located at Big Sheep Mountain (elevation 1094 meters) near the RedwaterYellowstone River drainage divide's southwest end. Note in Figure 2 how Big Sheep Mountain extends in a northwest-to-southeast direction between a southeast- and an east-oriented Yellowstone River tributary and that Redwater River tributaries near Big Sheep Mountain are oriented in northwest directions (just to the east of Figure 2 the east-oriented Yellowstone tributary to the north of Big Sheep Mountain joins a southeast oriented Yellowstone River tributary). These observations suggest that southeast-oriented water moving into the northeast-oriented Yellowstone River valley sculpted the Big Sheep Mountain upland and Redwater River valley headward erosion captured that southeast-oriented water and diverted the water in a north direction to the Missouri River. If correctly interpreted the northwest-oriented Redwater River and Big Dry Creek tributaries seen in Figure 2 were formed by reversals of flow along what had been multiple and closely spaced southeast-oriented flow channels.

The Redwater River headwaters area also illustrates what was necessary for alluvium from upstream Yellowstone River drainage basin source areas to enter the Redwater River drainage basin. To do so a northeast-oriented river following the present-day Yellowstone River alignment must have transported the alluvium, but at an elevation high enough to deposit alluvium on Big Sheep Mountain. Today Big Sheep Mountain is the region's highest point and erosion has inverted the regional topography. Colton et al (1994) mapped alluvium on Big Sheep Mountain as Miocene and Pliocene in age, although Clausen (2018d) reported alluvium found in the Big Sheep Mountain area matches alluvium found in mapped southwest North Dakota Oligocene and much younger deposits. Important to this paper is alluvium containing the same types of distinctive rock types as are found on the Big Sheep Mountain can be found throughout the Redwater River drainage basin. To reach some Redwater River drainage basin areas where that distinctive alluvium is found Redwater River valley headward erosion must have occurred when large volumes of water flowed from elevations equivalent to the present day Redwater-Yellowstone River drainage divide elevation into the Redwater River drainage basin. Such a scenario would not have been possible if the deep Yellowstone River valley now present to the east and south of figure 2 had existed at that time. 


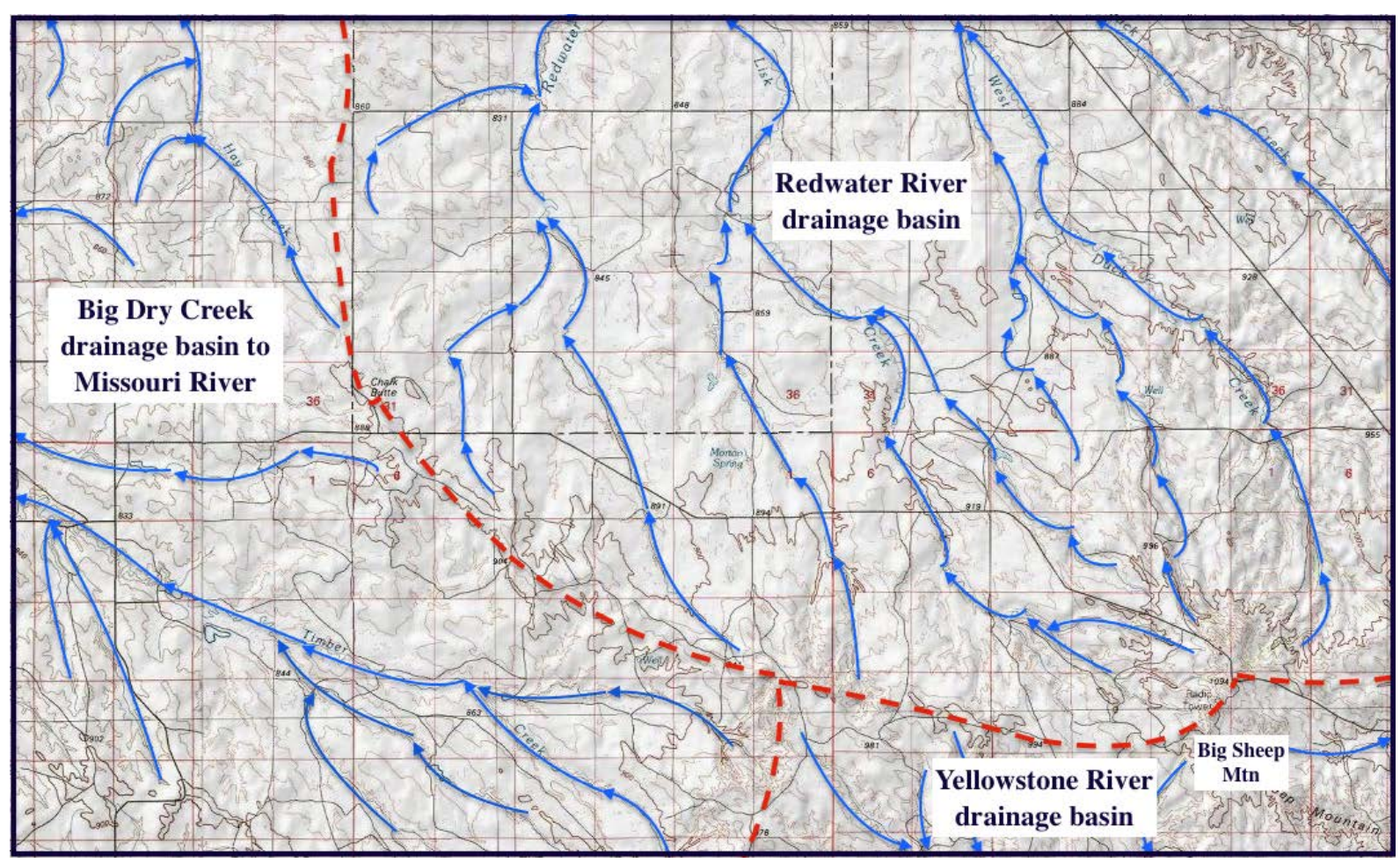

Figure 2. Modified topographic map from USGS National Map website showing the Redwater River headwaters area. Blue arrows emphasize drainage routes and directions and dashed red lines show major drainage divides. The contour interval is 20 meters and sides of grid squares are 1 mile (1.6 kilometers). The highest point at Big Sheep Mountain is 1094 meters.

\subsection{Redwater-Yellowstone River Drainage Divide}

The asymmetric Redwater-Yellowstone River drainage divide extends in a northeast direction from the Big Sheep Mountain area seen in Figure 2 as a high ridge drained by southeast-oriented streams flowing as barbed tributaries to the northeast-oriented Yellowstone River and by northwest-oriented streams flowing to the Redwater River. Drainage divide elevations gradually decrease from a high of 1094 meters at Big Sheep Mountain to approximately 1000 meters in Figure 3, to about 900 meters in figure 4 and then to about 727 meters at Enid, Montana where a 100-meter deep valley links northwest-oriented Redwater Creek headwaters (flowing to the Redwater River) with headwaters of southeast-oriented Fox Creek (which eventually turns in a northeast direction before joining the northeast-oriented Yellowstone River). To the northeast of the deep valley at Enid the drainage divide rises to more than 840 meters before decreasing to about 800 meters where the Redwater-Yellowstone River drainage divide ends and the Charley Creek-Yellowstone River drainage divide begins (Charley Creek is a north-oriented Missouri River tributary located between the Redwater River and the Yellowstone River). Glacial Lake Circle hypothesis advocates explain the deep valley at Enid as the Glacial Lake Circle outlet, although the valley is hardly large enough to have handled all of the projected ice-marginal flow and the Glacial Lake Circle outlet hypothesis does not address why Redwater River tributaries are oriented in northwest directions and Yellowstone River tributaries in southeast directions nor does it explain the numerous other less deep and higher elevation dry valleys also crossing the Redwater-Yellowstone drainage divide (such as those seen in Figures 3 and 4). 


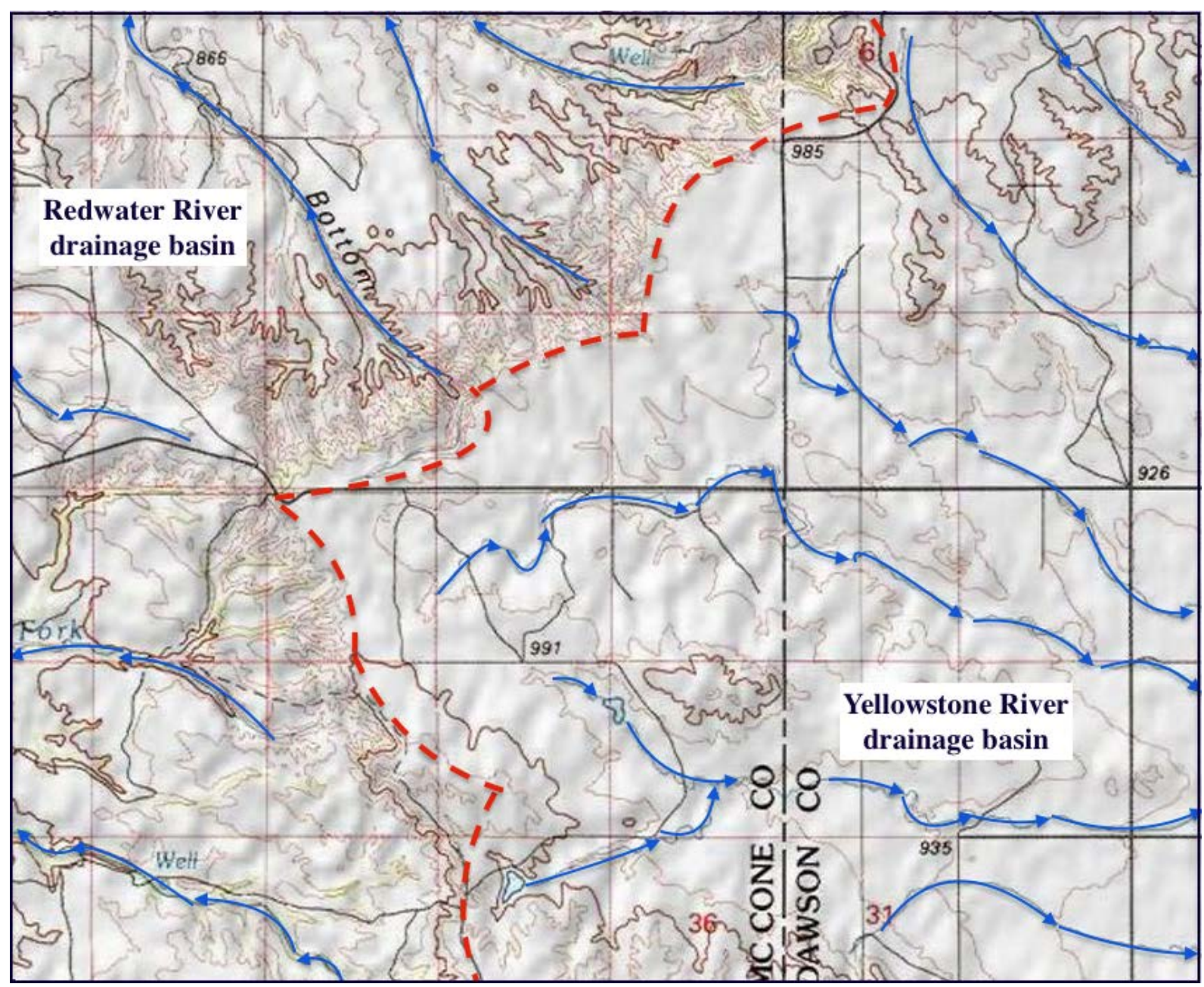

Figure 3. Modified topographic map from the USGS National Map website showing a Redwater-Yellowstone River drainage divide segment to the northeast of figure 2. Blue arrows emphasize drainage routes and directions and the dashed red line shows the drainage divide location. Sides of squares in the grid are 1 mile (1.6 kilometers) and the contour interval is 20 meters.

Figure 3 illustrates a Redwater-Yellowstone River drainage divide area located to the northeast of Figure 2 and to the southwest of Figure 4. Note how the drainage divide is asymmetric with steeper slopes on the Redwater River drainage basin side than on the Yellowstone River drainage basin side. Further observe how Yellowstone River tributaries flow in southeast directions while Redwater River tributaries flow in northwest directions. The dark contour line crossing the drainage divide near the south and north edges of Figure 3 is the 1000-meter contour line and drainage divide elevations near the south and north edges exceed 1000 meters while drainage divide elevations in the Figure 3 center are mostly lower than 1000 meters. What must have been a broad sheet of water flowing in a southeast direction from what is today the Redwater River drainage basin into the Yellowstone River valley must have eroded the broad shallow valley now crossing the drainage divide seen in Figure 3 . The explanation that a 1000-meter high glacially dammed lake filled a pre-existing Redwater River valley and overflowed into the Yellowstone River, while possibly accounting for the broad shallow valley now crossing the drainage divide and the southeast-orientation of the Yellowstone River tributaries, does not account for similar features at the higher elevation Big Sheep Mountain location seen in Figure 2, the asymmetric drainage divide or the northwest-oriented Redwater River tributary orientations seen in Figure 3. However, all of these features can be explained if the Redwater River valley eroded headward across massive ice-marginal southeast-oriented flood flow. 


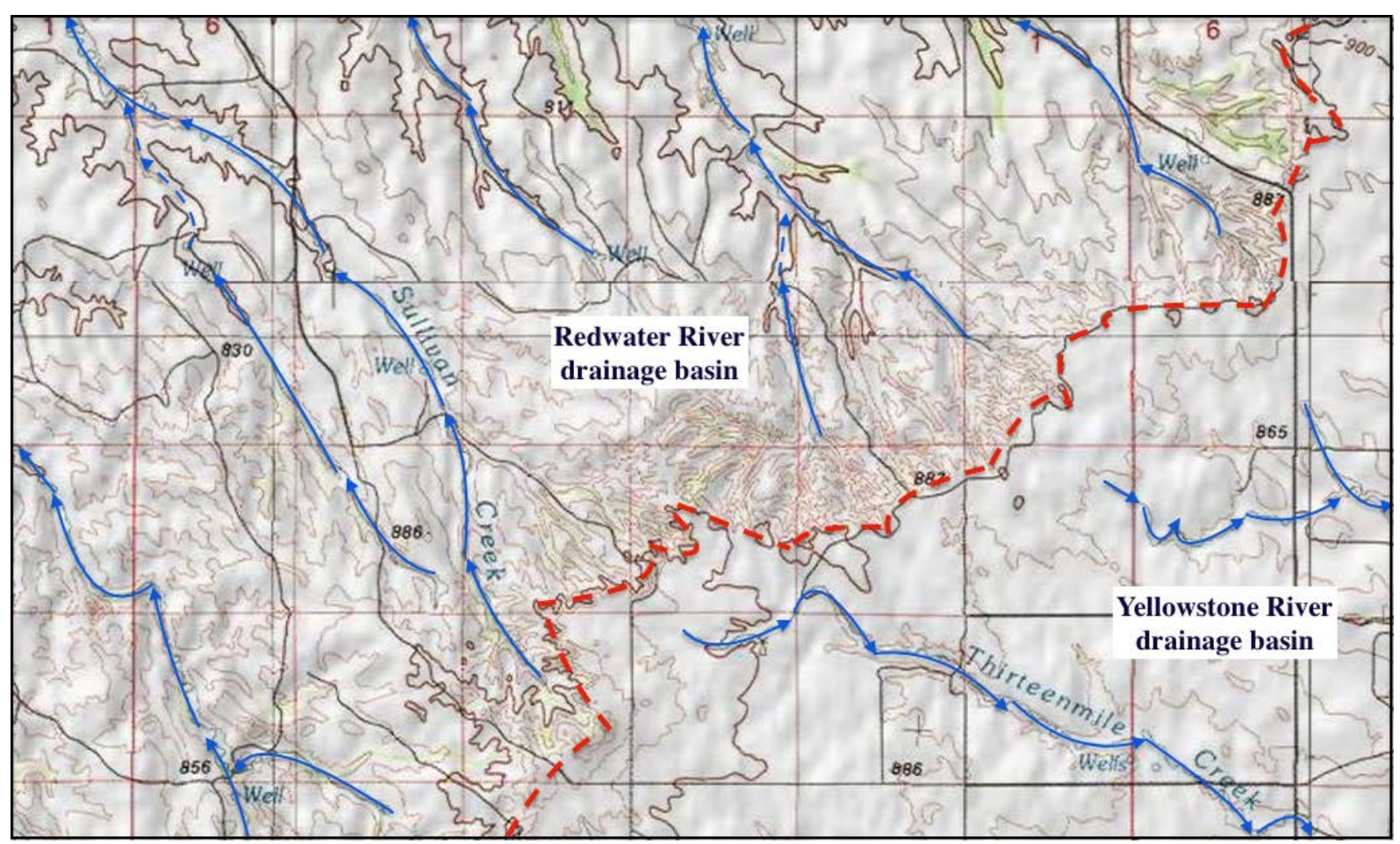

Figure 4. Modified topographic map from the USGS National Map website showing another RedwaterYellowstone River drainage divide segment. The dashed red line follows the drainage divide and blue arrows emphasize drainage routes and directions. Sides of grid squares are 1 mile (1.6 kilometers) and the contour interval is 20 meters

Figure 4 illustrates the Redwater-Yellowstone River drainage divide to the northeast of Figure 3 and to the southwest of the previously mentioned hypothesized Glacial Lake Circle outlet at Enid. Figure 4 also shows a broad shallow valley crossing the asymmetric Redwater-Yellowstone River drainage divide. The dark contour line surrounding the southwest end of the drainage divide seen in Figure 4 represents 900 meters and is seen again in small patches along the Figure 4 drainage divide and then again in the northeast corner of Figure 4. Between those 900-meter plus high regions are slightly lower regions again suggesting that multiple streams or sheets of southeast-oriented water once flowed across this drainage divide segment in a southeast-direction from where the present day Redwater River drainage basin is located into the northeast-oriented Yellowstone River valley. Again, it could be argued that water from a glacially dammed lake filling a pre-existing Redwater River drainage basin had overflowed and spilled across the drainage divide with water flowing in a southeast direction to enter the northeast-oriented Yellowstone River valley. However, such an explanation does not address the asymmetric drainage divide or the northwest orientation of the Redwater River tributaries, nor does it explain evidence seen in Figure 2 (Big Sheep Mountain area where elevations reach 1094 meters) or seen in Figure 3 (where elevations are in the 1000-meter range). Again, a hypothesis that the north-oriented Redwater River valley (and drainage basin) eroded headward across massive southeast-oriented ice-marginal melt water floods moving into what was at that time an actively eroding northeast-oriented Yellowstone River valley better explains the evidence.

\subsection{Redwater River Tributaries}

Figure 5 uses a modified topographic map from the USGS National Map website to illustrate how Redwater River tributaries from the southeast generally flow in northwest directions and tributaries from the northwest are generally barbed tributaries flowing in southeast directions to join the northeast-oriented Redwater River. This tributary orientation is seen where the Redwater River is oriented in a northeast direction except in its lower reaches after the Redwater River has entered the mapped glaciated region. Once in that mapped glaciated region and after crossing the 660-meter contour line the Redwater River turns from flowing in a northeast direction to flow in a north direction and then in a northwest direction before finally turning in a meandering northeast direction to enter the east-oriented Missouri River. In this northern glaciated and lower elevation region the Redwater River still has northwest- and southeast-oriented tributaries, but it also has tributaries oriented in different directions and complex tributaries including a northeast-oriented tributary with northwest- and southeast-oriented tributaries of its own. 


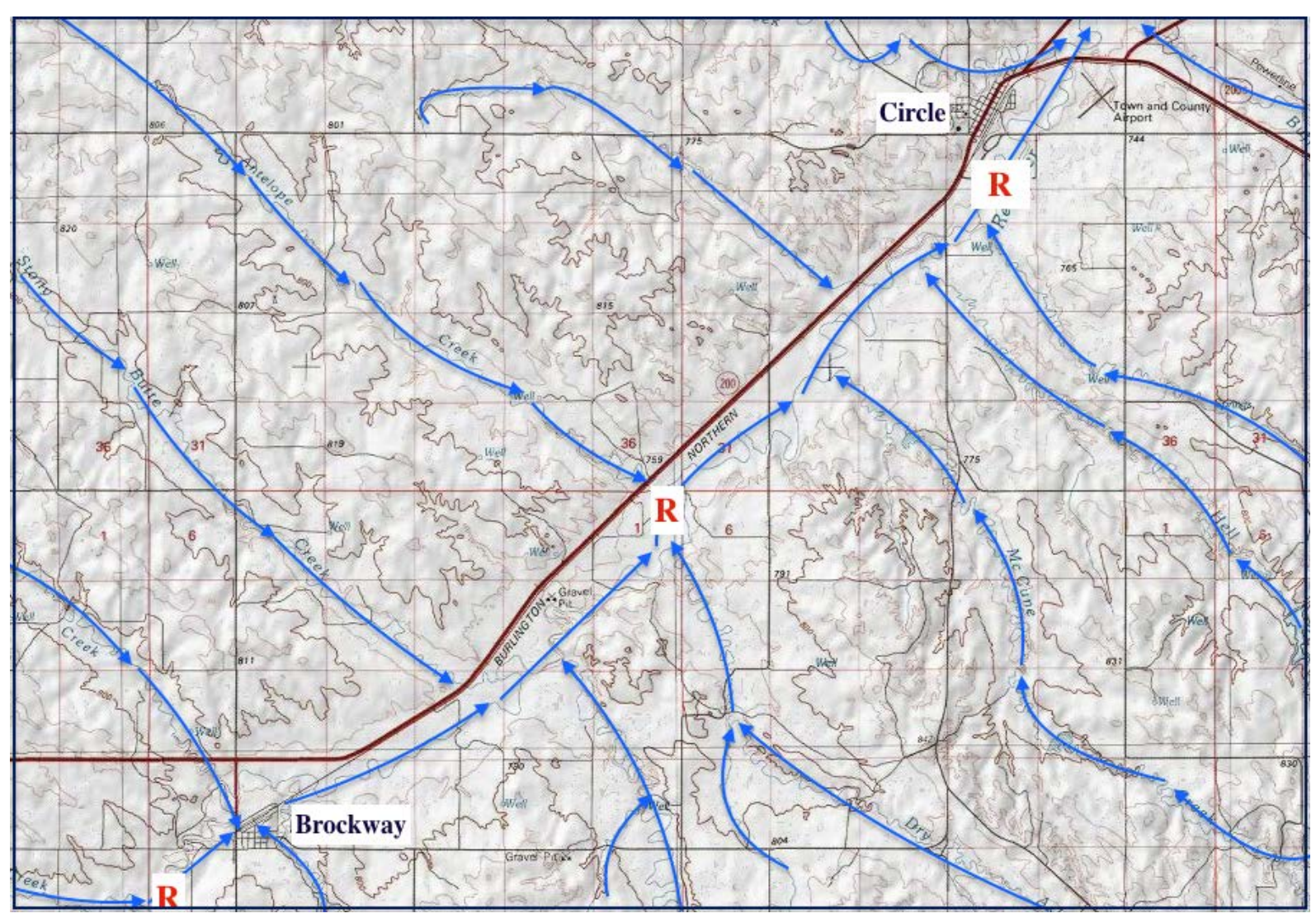

Figure 5. Modified topographic map from the USGS National Map website showing tributaries entering the Redwater River segment between the Montana towns of Brockway and Circle. Blue arrows emphasize stream locations and directions and the red letter "R" identifies the Redwater River. Sides of grid squares are one mile (1.6 kilometers) and the contour interval is 20 meters.

Previous investigators have not addressed reasons for the Redwater River drainage basin's northwest- and southeast-oriented drainage routes seen in Figure 5, although previous workers have discussed similar Great Plains northwest-southeast drainage route alignments (Thornbury, 1965). Several investigators including Russell (1929), Flint (1955), Crandell (1958), and Whitney (1985) used the prevailing Great Plains region wind direction to explain aligned drainage routes. Other workers used aligned drainage to identify lineaments (Shurr, 1982). Clausen in a series of recent papers has presented evidence suggesting immense southeast-oriented ice-marginal melt water floods produced the observed aligned drainage. For example, Clausen (2018c) attributed aligned drainage in the Beaver Creek drainage basin along the Montana-North Dakota border (located to the east of the Redwater River drainage basin) to massive southeast-oriented ice-marginal melt water floods. Such an explanation requires the deep Redwater River valley to have eroded headward from the continental ice sheet margin across immense southeast-oriented ice-marginal melt water floods and the melting ice sheet floor elevation to have been lower in elevation than ice-marginal areas and further requires the ice sheet to have melted in a way that opened up space on the decaying ice sheet's floor while large melt water floods also flowed along the ice sheet margin.

\subsection{Redwater River Drainage Basin Western Margin}

Sand Creek is a north-oriented Missouri River tributary located to the west of northern Redwater River drainage basin areas, Prairie Elk is a somewhat longer north-oriented Missouri River tributary located to the west of the Sand Creek and Redwater River drainage basins, and Big Dry Creek is an even longer north-oriented Missouri River tributary located to the west of the Prairie Elk Creek and Redwater River drainage basins. Elevations along the Redwater River drainage divide with Sand, Prairie Elk, and Big Dry Creeks are generally 100 meters (or more) lower than corresponding elevations along the drainage divide between the Redwater River and the Yellowstone River. Most east-oriented tributaries originating along the drainage divides between the Redwater River and Sand, Prairie Elk, and Big Dry Creeks initially flow in southeast directions while most west-oriented tributaries initially flow in northwest directions, although some interesting exceptions exist. 
One interesting exception is Cow Creek, which originates as a northwest-oriented stream flowing toward the Sand Creek-Redwater River drainage divide before turning in a northeast direction to flow parallel to the nearby Redwater River-Sand Creek drainage divide and finally turning in a southeast direction to join the Redwater River as a barbed tributary. Figure 6 provides a detailed topographic map of the region where Cow Creek (identified by the letter C) turns from flowing in a northeast direction to flow in a southeast direction. Note the northwest-tosoutheast oriented dry valley crossing the Sand Creek-Redwater River drainage divide located immediately to the northwest of the Cow Creek turn. The spot elevation at the number 1, where the drainage divide crosses the dry valley floor, reads 2516 feet (767 meters) and the spot elevation at the number 2 reads 2621 feet (799 meters) while the elevation at the number 3 exceeds 2640 feet (805 meters) indicating the valley is more than 100 feet (30.5 meters deep). Water moving in a southeast direction from the present-day Sand Creek drainage basin into the present day Redwater River drainage basin eroded the observed dry valley. Upstream along the northeast-oriented Cow Creek segment from the Figure 6 location Cow Creek is joined by short southeast-oriented tributaries linked by much shallower dry valleys with northwest-oriented Sand Creek tributaries and the northwest-oriented Cow Creek headwaters is linked by a shallow dry valley with a southeast-oriented Redwater River tributary suggesting that at one time southeast-oriented water flowed across the entire Sand Creek-Cow Creek drainage divide and the northeast-oriented Cow Creek valley eroded headward across what must have been southeast-oriented flood flow.

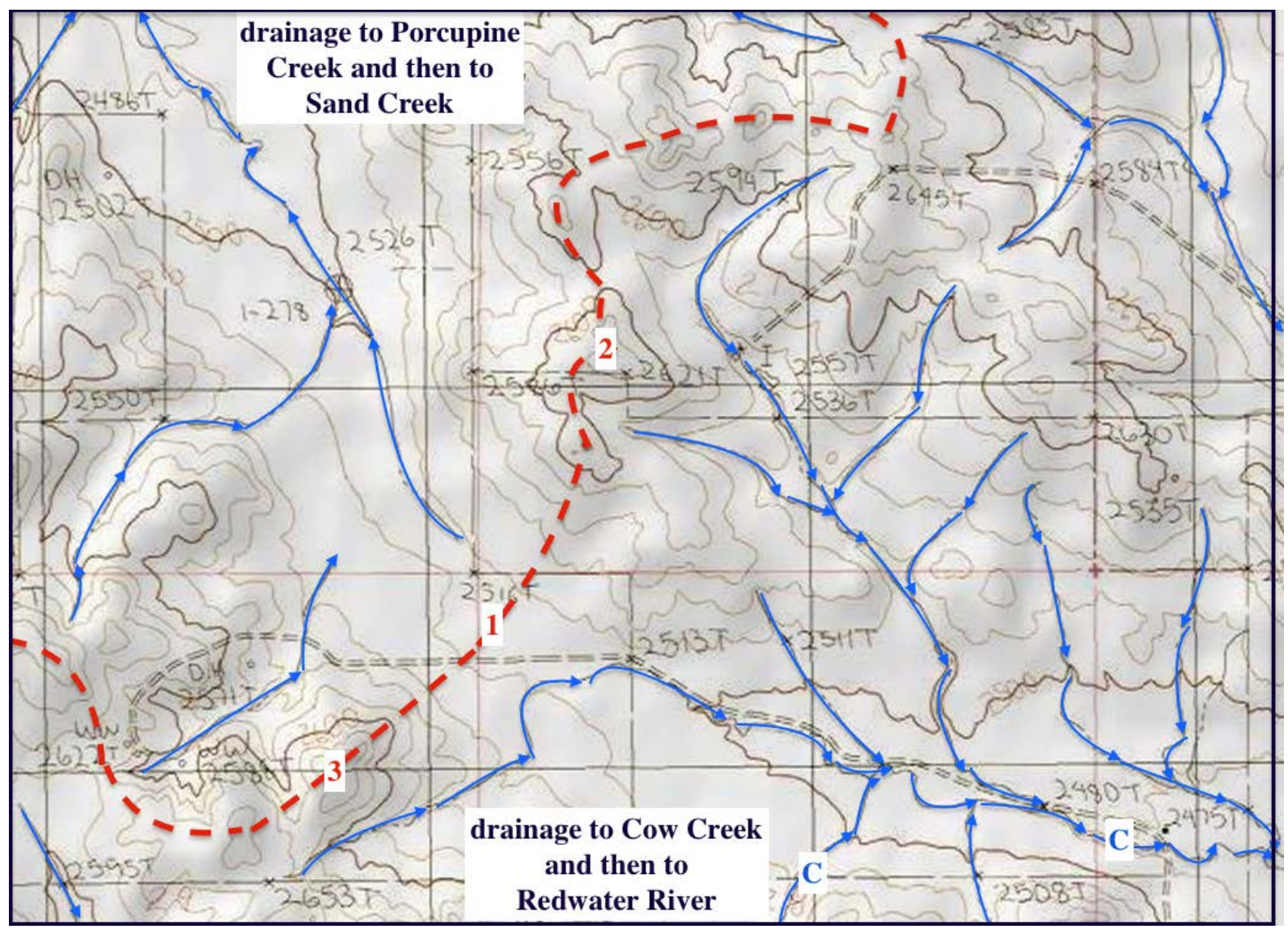

Figure 6. Modified detailed topographic map from the USGS National Map website showing a segment of the Sand Creek-Redwater River drainage divide. Blue arrows emphasize drainage routes and directions and the dashed red line shows the drainage divide location. Sides of grid squares are 1 mile (1.6 kilometers) and the contour interval is 20 feet (6 meters).

A somewhat shallower dry valley, although similar to the dry valley seen in Figure 6, crosses the Prairie Elk CreekRedwater River drainage divide and links the northwest-oriented Prairie Elk Creek headwaters with the headwaters of southeast-oriented Denwoody Creek, which is a tributary to southeast-oriented Horse Creek, which joins the northeast-oriented Redwater River as a barbed tributary. This shallow dry valley provides evidence water once flowed from the present-day Prairie Elk Creek drainage basin into the Redwater River drainage basin. Further to the south multiple shallow dry valleys link northwest-oriented McGuire Creek headwaters (flowing to Big Dry Creek) with southeast-oriented Horse Creek headwaters. Continuing to the south shallow dry valleys link 
northwest-oriented Nelson Creek headwaters with southeast-oriented Stony Butte, Cotter, and Beauty Creeks and cross the Big Dry Creek-Redwater River drainage divide. Still further to the south shallow dry valleys cross the Big Dry Creek-Redwater River drainage divide and link northwest-oriented Hay Creek with northeast-oriented Redwater River headwaters. The dry valley floor elevations increase in a south direction with the southernmost of the Hay Creek-Redwater River drainage divide shallow dry valleys having a floor elevation greater than 2880 feet (878 meters) or more than 364 feet (111 meters) higher than the dry valley crossing the Sand Creek-Cow Creek drainage divide seen in Figure 6. These dry valleys indicate that southeast-oriented water once flowed across the Redwater River drainage basin's entire western drainage divide.

\section{Discussion}

Dry valleys crossing the Redwater River drainage divides, the asymmetric Redwater-Yellowstone River drainage divide, the southeast-oriented barbed tributaries joining the northeast-oriented Redwater River, and the pronounced northwest and southeast alignments of streams flowing in opposite directions from drainage divides surrounding the Redwater River drainage basin all strongly suggest the north-oriented Redwater River valley eroded headward across large southeast-oriented ice-marginal floods. The modern day Redwater-Yellowstone River drainage divide elevation and the presence of distinctive Yellowstone River drainage basin alluvium in the Redwater River drainage basin further suggest the massive southeast-oriented floods flowed on a regional surface equivalent in elevation to, if not higher, than the Big Sheep Mountain elevation. Deep erosion must have occurred and inverted the regional topography, probably as headward erosion of the deep north-oriented Yellowstone and Redwater River valleys diverted massive ice-marginal floodwaters into space the melting ice sheet had once occupied.

Such an interpretation while consistent with the detailed topographic map and alluvium evidence presented here requires the continental ice sheet floor to have been lower in elevation than adjacent ice-marginal regions. Such a situation would be expected if the ice sheet deeply eroded the underlying bedrock and was occupying a deep "hole." Space on the floor of such an ice sheet could have opened up when large supra-glacial melt-water rivers sliced icewalled and bedrock-floored canyons into the decaying ice sheet's surface. Several of Clausen's recent papers describe how one ice-walled and bedrock-floored canyon detached the ice sheet's southwest margin by slicing a southeast- and south-oriented ice-walled and bedrock-floored canyon into the ice sheet's surface. The Missouri Escarpment seen in Figure 1 is what remains of that canyon's southwest and west wall. Since the canyon's floor was lower in elevation than elevations of the large southeast-oriented ice-marginal floods to the south and west of the ice sheet's detached and decaying margin, water from massive ice-marginal floods eventually could spill across the ice sheet margin and enter the ice-walled and bedrock floored canyon with spillages beginning in the southeast and progressing to the northwest. Such spillages enabled a progression of north- and northeast-oriented valleys to erode headward from the ice-walled canyon floor across the ice sheet's detached margin and diversion of large ice-marginal melt water floods onto the much lower ice sheet floor.

Using the above described model spillages of ice-marginal floodwater across the decaying ice sheet's southwest margin enabled the Yellowstone River valley and next the valley at location V on Figure 1 (leading to the Redwater and the Missouri River valleys) to erode headward with the north-oriented Yellowstone River valley eroding headward across the massive southeast-oriented ice-marginal floods slightly in advance of Redwater River valley headward erosion, which was slightly in advance of the northeast-oriented Missouri River valley's headward erosion (and of headward erosion of north-oriented Missouri River tributary valleys to the west of the Redwater River valley). Headward erosion of each successive north-oriented valley captured the immense southeast-oriented ice-marginal floods and ended flow to the newly eroded north-oriented valley immediately to the east. At first floodwaters were diverted onto the decaying ice sheet's floor where the floodwaters flowed on the floor of an icewalled and bedrock-floored canyon until they emerged in what is now southeast South Dakota and eroded what is now the much wider Missouri River valley along the Nebraska-Iowa border (see Clausen, 2018c).

While not addressed by evidence presented here several of Clausen's recent papers suggest ice sheet decay eventually opened up north-oriented ice-walled and bedrock-floored canyons so as to divert the massive southeastoriented ice marginal melt water floods onto north-oriented routes that previous investigators have described as the pre-glacial Bell River drainage system. This diversion of the immense south-oriented melt water floods from the Gulf of Mexico to become north-oriented floods flowing into the North Atlantic Ocean triggered a major climate change. The decaying ice sheet's rapid melting ended and the north-oriented floodwaters (and drainage captured by headward erosion of the newly eroded north-oriented valleys such as the Yellowstone and Redwater River valleys) began to freeze on the ice-walled and bedrock-floored canyon floors between the decaying ice sheet remnants so as to create a new and much thinner ice sheet. This new ice sheet did not deeply erode underlying bedrock, but was responsible for depositing materials in the Bell River drainage system valleys and for blocking newly formed north-oriented drainage routes causing the blocked water to overflow along the new ice sheet's 
southern and southwestern margin so as to create the Missouri River route seen in figure 1.

\section{Conclusions}

Landforms as observed on detailed topographic maps strongly suggest the north-oriented Redwater River valley eroded headward from a continental ice sheet location across massive southeast-oriented ice-marginal melt water floods and are best explained from the context of the new regional geomorphology paradigm presented in several of Clausen's recent papers. Such an interpretation is contrary to most published regional geologic histories and is only possible if the continental ice sheet floor elevation from which headward erosion of the Redwater River valley occurred was significantly lower than the elevation of ice-marginal regions into which the Redwater River valley eroded, which means the continental ice sheet must have deeply eroded the easily eroded regional bedrock. If so the abandoned north-oriented Bell River drainage system of which the Redwater River valley is a southern extension and which most previous investigators claim has a pre-glacial origin, is in fact a drainage system developed late during the melting of a large North American continental ice sheet. That newly formed northoriented drainage system developed between decaying ice sheet remnants and triggered a major climatic change that froze the north-oriented melt water floods on the floors of canyons between decaying ice remnants to produce a second and much thinner ice sheet. That second ice sheet blocked the newly eroded north-oriented valleys near the decaying ice sheet's southwest margin. Those blockages may have produced short-lived ponding of northoriented drainage routes and definitely forced the water to flow along the second ice sheet's southwest margin so as to create the North and South Dakota and eastern Montana Missouri River valley.

\section{Acknowledgements}

Field work and much of the early topographic map interpretation work that led to this paper was done while employed as a faculty member at Minot State University (North Dakota) where other faculty members, library staff members, and students assisted in obtaining access to the needed detailed topographic maps.

\section{References}

Alden, W. C. (1932). Physiography and glacial geology of eastern Montana and adjacent areas: United States Geological Survey Professional Paper 174.

Clausen, E. (2017a). Using map interpretation techniques for relative dating to determine a western North Dakota and South Dakota drainage basin formation sequence, Missouri River drainage basin, USA. Journal of Geography and Geology, 9(4), 1-18. https://doi.org/10.5539/jgg.v9n4p1

Clausen, E. (2017b). Origin of Little Missouri River - South Fork Grand River and nearby Drainage Divides in Harding County, South Dakota and Adjacent Eastern Montana, USA. Open Journal of Geology, 7, 1063-1077. https://doi.org/10.4236/ojg.2017.78071

Clausen, E. (2018a). Belle Fourche River-Cheyenne River drainage divide area in the Wyoming Powder River Basin analyzed by topographic map interpretation methods, USA. Journal of Geography and Geology, 10(2), 1-16. https://doi.org/10.5539/jgg.v10n2p1

Clausen, E. (2018b). Probable deep erosion by continental ice sheet melt water floods: Chalk Buttes area of Carter County, Montana, USA. International Journal of Geography and Geography, 7(1), 14-28. https://doi.org/10.18488/journal.10.2018.71.14.26

Clausen, E. (2018c). Geomorphic history of the Beaver Creek drainage basin as determined from topographic map evidence: eastern Montana and western North Dakota, USA: Journal of Geography and Geology, 10(3), 7991. https://doi.org/10.5539/jgg.v10n3p79

Clausen, E. (2018d). Interpreting topographic map evidence related to northeast Nebraska barbed tributaries and drainage routes, USA. Journal of Geography and Geology, 10(2), 66-79. https://doi.org/10.5539/jgg.v10n2p66

Colton, R. B., Lemke, R. W., \& Lindvall, R. M. (1961). Glacial map of Montana east of the Rocky Mountains: United States Geological Survey Miscellaneous Investigations Map 1-327.

Colton, R. B., McGrew, J. P., \& Bozeman, D. K. (1994). Geologic map of the Big Sheep Mountain quadrangle, Prairie County, Montana: United States Geological Survey Open-File Report, 93-529. https://doi.org10.3133/ofr93529

Crandell, D. R. (1958). Geology of the Pierre area, South Dakota: United States Geological Survey Professional Paper 307, 83p. https://doi.org/10.3133/pp307

Davis, N. K. (2004). Extent and timing of Laurentide Glacial Lake Musselshell, Central Montana: Master of 
Science thesis, Montana State University, Bozeman, Montana, 202 p.

Denson, N. M., \& Gill, J. R. (1965). Uranium-bearing lignite and carbonaceous shale in the southwestern part of the Williston Basin-a regional study: United States Geological Survey Professional Paper 463, 75p.

Flint, R. F. (1955). Pleistocene geology of eastern South Dakota: United States Geological Survey Professional Paper 262, 174 p. https://doi.org/10.3133/pp262

Howard, A. D. (1958). Drainage evolution in northeastern Montana and northwestern North Dakota. Bulletin of the Geological Society of America, 69, 575-588. https://doi.org/10.1130/00167606(1958)69[575:DEINMA]2.0.CO;2

Howard, A.D. (1960). Cenozoic history of northeastern Montana and northwest North Dakota with emphasis on the Pleistocene: United States Geological Survey Professional Paper 326, 107 p.

Kuhn, T. (1965). The Structure of Scientific Revolutions: Second edition, enlarged: University of Chicago Press, $210 \mathrm{p}$.

Leonard, A. G. (1916). Pleistocene drainage changes in western North Dakota. Geological Society of America Bulletin, 27(1), 295-304. https://doi.org/10.1130/GSAB-27-295

McMillan, J. N. (1973). Shelves of the Labrador Sea and Baffin Bay, Canada: Canadian Society of Petroleum Geologists Memoir, 1, 473-515.

Parker, F. S. (1936). The Richey-Lambert coalfield: Richland and Dawson Counties, Montana: United States Geological Survey Bulletin 847-C, p. 136-139.

Russell, W. L. (1929). Drainage alignment in the western Great Plains. Journal of Geology, 37, 249-255. https://doi.org/10.1086/623618

Sears, J. W. (2013). Late Oligocene-early Miocene Grand Canyon: A Canadian connection? GSA Today, 23(11), 4-10. https://doi.org/10.1130/GSATG178A.1

Shurr, G.W. (1982). Geological significance of lineament interpreted from Landsat images near the northern Black Hills. In Christopher, J.E. and Kaldi, J. (Eds.). Fourth International Williston Basin Symposium: Saskatchewan Geological Society Special Publication 6, 313-320.

Sugden, D. E. (1976). A case against deep erosion of shields by continental ice sheets: Geology, 4, 580-582. https://doi.org/10.1130/0091-7613(1976)4<580:ACADEO>2.0.CO;2

Thornbury, W. D. (1965). Regional Geomorphology of the United States: John Wiley and Sons, New York, 609 p.

Todd, J. E. (1914). The Pleistocene history of the Missouri River. Science, 39, 263-274. https://doi.org/10.1126/science.39.999.263

White, W. A. (1972). Deep erosion by continental ice sheets. Geological Society of America Bulletin, 81(4), 10371056. https://doi.org/10.1130/0016-7606(1972)83[1037:DEBCIS]2.0.CO;2

White, W. A. (1988). More on deep glacial erosion by continental ice sheets and their tongues of distributary ice. Quaternary Research, 30(2), 137-150. https://doi.org/10.1016/0033-5894(88)90019-1

Whitney, M.L. (1985). Yardangs. Journal of Geological Education, 33, 93-100. https://doi.org/10.5408/00221368-33.2.93

Wilde, E. M., \& Smith, L. N. (2003). Geologic and structure contour map of the Richey 30' x 60' quadrangle, eastern Montana (scale 1:100,000). Montana Bureau of Mines and Geology Open-File Reports MBMG-475.

\section{Copyrights}

Copyright for this article is retained by the author(s), with first publication rights granted to the journal.

This is an open-access article distributed under the terms and conditions of the Creative Commons Attribution license (http://creativecommons.org/licenses/by/4.0/). 